\title{
Oral vitamin D supplementation has a lower bioavailability and reduces hypersecretion of parathyroid hormone and insulin resistance in obese Chinese males
}

\author{
Ji-Chang Zhou ${ }^{1}$, Yu-Mei Zhu ${ }^{1}$, Zheng Chen ${ }^{1}$, Jun-Luan Mo ${ }^{1}$, Feng-Zhu Xie ${ }^{2}$, \\ Ying-Hong Wen ${ }^{3}$, Ping Guo ${ }^{2}$, Ji Peng ${ }^{4}$, Jian Xu ${ }^{5}$, Jun Wang ${ }^{3}$ and Xiao-Li Liu ${ }^{5, *}$ \\ 'Molecular Biology Lab, Shenzhen Center for Chronic Disease Control (SZCCDC), Shenzhen, People's Republic of \\ China: ${ }^{2}$ Health Service Center of Shuiku Community, SZCCDC, Shenzhen, People's Republic of China: ${ }^{3}$ Outpatient \\ Department, SZCCDC, Shenzhen, People's Republic of China: ${ }^{4}$ Department of Chronic Disease Prevention, \\ SZCCDC, Shenzhen, People's Republic of China: ${ }^{5}$ Department of Health and Chronic Disease Management, \\ SZCCDC, 2021 Buxin Road, Luohu District, Shenzhen 518020, People's Republic of China
}

Submitted 8 May 2013: Final revision received 17 September 2014: Accepted 4 November 2014: First published online 17 December 2014

\begin{abstract}
Objective: To examine the vitamin D status, SNP of the vitamin D receptor gene $(V D R)$ and the effects of vitamin D supplementation on parathyroid hormone and insulin secretion in adult males with obesity or normal weight in a subtropical Chinese city.

Design: An intervention trial.

Setting: Shenzhen City, Guangdong Province, China.

Subjects: From a cross-sectional survey conducted from June to July, eighty-two normal-weight and ninety-nine obese males (18-69 years) were screened to analyse their vitamin D status and for five SNP of $V D R$. From these individuals, in the same season of a different year, obese and normal-weight male volunteers (twenty-one per group) were included for an intervention trial with oral vitamin D supplementation at $1250 \mu \mathrm{g} /$ week for 8 weeks.

Results: For the survey, there was no significant difference $(P>0.05)$ in baseline circulating 25-hydroxyvitamin $D$ concentrations or in the percentages of participants in different categories of vitamin D status between the two groups. The VDR SNP, rs3782905, was significantly associated with obesity $(P=0.043)$, but none of the examined SNP were correlated with serum 25-hydroxyvitamin D when adjusted for age, BMI and study group. After vitamin D supplementation, serum 25-hydroxyvitamin D concentration, hypersecretions of parathyroid hormone and insulin, and insulin resistance in the obese were changed beneficially $(P<0.05)$; however, the increase in serum 25 -hydroxyvitamin D was less than that of the normal-weight men.

Conclusions: For obese and normal-weight men of subtropical China, the summer baseline vitamin D status was similar. However, oral vitamin D supplementation revealed a decreased bioavailability of vitamin D in obese men and ameliorated their hypersecretion of parathyroid hormone and insulin resistance.
\end{abstract}

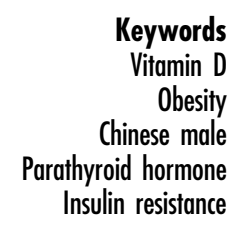

In China, approximately $12 \%$ of adult males are considered to be obese ${ }^{(1,2)}$. Since vitamin D nutritional status may be important in regulating obesity ${ }^{(3-6)}$, interest was aroused to study Chinese obese males in this regard. Circulating 25-hydroxyvitamin D (25(OH)D; calcidiol), a metabolite of vitamin D having a half-life of 2-3 weeks, is recommended as a reliable marker of vitamin $\mathrm{D}$ nutritional status $^{(7-10)}$. The US Institute of Medicine ${ }^{(11)}$ reports that a circulating 25(OH)D concentration equal to $50 \mathrm{nmol} / 1$ $(20 \mathrm{ng} / \mathrm{ml})$ meets the vitamin D requirements of $97.5 \%$ of the population, and this threshold is widely accepted for hypovitaminosis $\mathrm{D}^{(10,12-14)}$. Not satisfied with that basic requirement, many researchers claim that improvement of circulating $25(\mathrm{OH}) \mathrm{D}$ concentrations to much higher than $50 \mathrm{nmol} / 1$ can prevent a broad range of diseases ${ }^{(4,15-17)}$. In addition, $25(\mathrm{OH}) \mathrm{D} \leq 25 \mathrm{nmol} / 1(10 \mathrm{ng} / \mathrm{ml})$ is considered to be 'severe vitamin D deficiency', $75-250 \mathrm{nmol} / \mathrm{l}$ (30-100 ng/ml) a 'sufficient or optimal' level and 50-75 nmol/1 $(21-29 \mathrm{ng} / \mathrm{ml})$ an 'insufficient' level ${ }^{(12,13,18)}$, although these reference ranges are not defined by the Institute of 
Medicine ${ }^{(11)}$. Obesity is usually accompanied with low plasma or serum concentrations of vitamin $\mathrm{D}$ and its metabolite, $25(\mathrm{OH}) \mathrm{D}$, as they are fat-soluble and most likely sequestered into the fat cells ${ }^{(19-23)}$.

Low vitamin D nutritional status is associated with two common phenomena in obesity: hypersecretion of parathyroid hormone (PTH) and insulin resistance (IR). IR is a key pathological change that causes many obesity complications $^{(24,25)}$. The potential mechanism of vitamin D to improve insulin metabolism has been investigated ${ }^{(26)}$ and it has been postulated that improving vitamin D status in obese subjects can reduce IR and prevent chronic diseases $^{(27)}$. However, confounding factors such as race ${ }^{(26)}$, body size ${ }^{(28)}$ and others ${ }^{(29)}$ mean that identifying an association between vitamin D and elevated IR pathology is difficult. The relationship between vitamin D deficiency and high serum PTH is more clearly defined ${ }^{(15,30)}$. Under conditions of deficient $25(\mathrm{OH}) \mathrm{D}$ supply and decreasing tendency of 1,25-dihydroxyvitamin D $\left(1,25(\mathrm{OH})_{2} \mathrm{D}\right.$; calcitriol) production, decreased PTH synthesis up-regulates $25(\mathrm{OH}) \mathrm{D}-1-\alpha$-hydroxylase to stabilize the circulating and intercellular $1,25(\mathrm{OH})_{2} \mathrm{D}$ concentrations ${ }^{(30,31)}$. Aside from regulating $\mathrm{Ca}$ homeostasis, $1,25(\mathrm{OH})_{2} \mathrm{D}$ has multiple roles after binding with the vitamin $\mathrm{D}$ receptor (VDR) in target tissues. During adipocyte differentiation, VDR mRNA level changes ${ }^{(32,33)}$ and plays a key role in mediating the actions of $1,25(\mathrm{OH})_{2} \mathrm{D}^{(34)}$. The SNP of the $V D R$ gene may affect its own transcription ${ }^{(35)}$ or protein activity ${ }^{(36)}$. Interestingly, SNP of $V D R$ are associated with numerous diseases ${ }^{(37,38)}$, including obesity ${ }^{(39,40)}$.

Owing to differences in living circumstances, dietary patterns and genetic background, the vitamin D status, VDR SNP profiles and the effects of oral vitamin D supplementation in obese subjects are not well known. We therefore examined the effects of these factors on vitamin D, PTH and IR status in a population of obese Chinese males in the city of Shenzhen (latitude $22 \cdot 5^{\circ} \mathrm{N}$ ).

\section{Experimental methods}

\section{Cross-sectional survey}

The 'Shenzhen Survey for Chronic Diseases and Related Risk Factors 2009' was conducted from 1 June to 31 July of 2009, using a stratified, multistage, cluster sampling method. This survey involved 3746 adult males (age 18-69 years) who had lived in Shenzhen, China for $\geq 5$ years $^{(41)}$. From this epidemiological survey, individuals meeting the following criteria were included for the comparative analysis on obese and normal-weight males: (i) an obese group, with $\mathrm{BMI} \geq 28.0 \mathrm{~kg} / \mathrm{m}^{2(42)}$; (ii) a normalweight group, with $18.5 \mathrm{~kg} / \mathrm{m}^{2} \leq \mathrm{BMI}<24.0 \mathrm{~kg} / \mathrm{m}^{2(42)}$, and normal values for blood pressure, fasting plasma glucose, lipids, uric acid and creatinine being apparent; and (iii) all were Han Chinese and did not smoke, drink nor take vitamin $\mathrm{D}$ supplements in the past $>2$ years.

\section{Oral vitamin $D$ supplementation trial protocol}

From June to August of 2011, a human intervention trial was conducted with volunteers from the above crosssectional survey who were living in the community where the Shenzhen Center for Chronic Disease Control is located. The trial was approved by the Ethics Committee of the Center. The trial number registered on the ClinicalTrials. gov site is NCT01781169. After signing the informed consent form, the accepted adult Chinese males were grouped into an obese group (twenty-two participants) and a normal-weight group (twenty-one participants). The sample sizes for both groups also met those calculated based on their circulating $25(\mathrm{OH}) \mathrm{D}$ concentrations with $95 \%$ confidence interval and an expected sampling error of $5 \mathrm{nmol} / \mathrm{l}$. In addition to the inclusion criteria in the casecontrol study, the following criteria were also met for both groups: (i) non-vegetarian; (ii) fasting serum glucose $<7 \cdot 0 \mathrm{mmol} / \mathrm{l}$; (iii) serum glucose $2 \mathrm{~h}$ after $75 \mathrm{~g}$ oral glucose loading $<11.1 \mathrm{mmol} / \mathrm{l}$; and (iv) normal functioning of liver and kidney evaluated by alkaline phosphatase, aspartate aminotransferase, creatinine and uric acid. Information about intake of foods containing vitamin $\mathrm{D}$ in the past year, health status and other lifestyle factors in the past 5 years was collected by face-to-face interview with a set of questionnaires. Food replicas (Zhending Computer Technology Co., Ltd, Shanghai, China) were used to facilitate the recall of food intakes. Vitamin D intakes were estimated according to the participants' food intake and the reference vitamin D contents of foods published by the US Department of Agriculture ${ }^{(43)}$. Anthropometric parameters including height, body weight, skinfold thickness, waist circumference and hip circumference were measured according to standard protocols ${ }^{(44)}$.

With the baseline information and blood samples of fasting state and oral glucose tolerance testing collected in late June, all participants received the oral vitamin D intervention starting from the same day in the catering division of the Shenzhen Center for Chronic Disease Control. Based on previous supplement methods ${ }^{(12,45-47)}$, every participant of the two groups consumed an oral capsule containing $50000 \mathrm{IU}(1250 \mu \mathrm{g})$ of natural vitamin $\mathrm{D}_{3}$ (catalogue no. 7184-01; Bio-Tech Pharmacal, Inc., Fayetteville, AR, USA) with a meal once weekly for 8 weeks, under the observation of project staff. Any participant who would be inevitably absent from the observation of vitamin D intake informed the project staff in advance to get the vitamin D capsule and reported the scheduled intake via telephone. During the vitamin D supplementation period, the participants were required to maintain their normal living and eating habits. Every other day, a telephone interview was conducted to know their duration of sun exposure, dress and usage of sunscreen and sunshade between 10.00 and 15.00 hours when exposure to UV light causes the most effective vitamin D synthesis in skin ${ }^{(48)}$, as well as to monitor symptoms of possible vitamin D toxicity, such as anorexia, nausea, 
vomiting, diarrhoea, constipation, continuous headaches, irregular heartbeat, muscle and bone pain, etc. ${ }^{(49)}$. These symptoms were also cared for by an endocrine physician when participants came to the catering division to take vitamin D supplements every week and clinical examinations would be done if necessary. One week after the last intake of vitamin D supplement, all biometric and biochemical measures were re-evaluated. The vitamin D intake in the past 8 weeks was surveyed again by face-to-face interview with the FFQ and food replicas.

\section{Sample collection and preparation}

In the cross-sectional study, overnight fasting ( $>10 \mathrm{~h})$ blood samples were drawn from the ulnar vein and collected in sodium fluoride/potassium oxalate tubes. Within $2 \mathrm{~h}$, the plasma was separated for subsequent chemical analyses and blood cells were collected for DNA extraction. In the intervention trial, fasting blood was collected in a vacuum tube without anticoagulant for serum separation and a K-EDTA tube for whole blood parameter assays. Samples were used for some instant determinations or stored at $-75^{\circ} \mathrm{C}$ for later use.

\section{Biochemical analysis}

Serum insulin was analysed with a chemiluminescence kit (catalogue no. 33410; Beckman Coulter Inc., Guangzhou, China) in an automatic immunoassay analyser (ACCESS2; Beckman Coulter Inc.). Glucose, TAG, total cholesterol, HDL cholesterol, LDL cholesterol, uric acid, creatinine, alkaline phosphatase and aspartate aminotransferase were analysed with an automatic biochemical analyser (AU400; Olympus Co., Ltd, Beijing, China). The IR status was evaluated with the homeostasis model assessment of insulin resistance index (HOMA-IR) ${ }^{(50)}$. The calculation was: HOMA-IR = fasting serum glucose $(\mathrm{mmol} / \mathrm{l}) \times$ fasting serum insulin (mIU/1)/22.5. Whole-blood Ca was determined with atomic absorption spectrometry (BH5100; Bohui Innovation Technology Co., Ltd, Beijing, China).

Using a microplate reader (Multiskan FC; Thermo Fisher Scientific Inc., Beijing, China), the $25(\mathrm{OH}) \mathrm{D}$ concentrations of all plasma and serum samples were measured by enzyme immunoassay (catalogue no. AC-57F1; IDS Ltd, Tyne \& Wear, UK). This method met the performance target set by the Advisory Panel of the Vitamin D External Quality Assessment Scheme. The intact PTH (iPTH) concentration of the fasting serum was also determined by enzyme immunoassay (catalogue no. 7022; Biomerica Inc., Irvine, CA, USA). The intra- and inter-assay CV for the $25(\mathrm{OH}) \mathrm{D}$ assay were $<8 \%$, and for the iPTH assay were $<7 \%$.

\section{Genotyping of SNP}

Five SNP, ApaI, TaqI, FokI, rs3782905 and $C d x$-2, of the $V D R$ were analysed using a PCR-restriction fragment length polymorphism method. Briefly, total DNA was extracted from approximately $200 \mu \mathrm{l}$ of anticoagulated whole blood with a DNA extraction kit (QIAamp DNA mini kit, catalogue no. 51106; QIAGEN Co., Ltd, Shanghai, China). Four pairs of primers were designed to amplify the four DNA fragments containing the five SNP, respectively (see online supplementary material, Supplemental Table 1). Approximately $1 \mu \mathrm{g}$ of the purified PCR product was then incubated with the corresponding restriction enzyme for ApaI, TaqI, FokI (catalogue no. D1005A, D1189A and D1046A, respectively; TaKaRa Biotech Co., Ltd, Dalian, China), DdeI (catalogue no. R6295; Promega Biotech Co., Ltd, Beijing, China) or BseMII (catalogue no. ER1401; Thermo Fisher Scientific Co., Ltd., Beijing, China) in a volume of $20 \mu \mathrm{l}$. Finally, the enzyme-digested product was loaded into a $2 \%(\mathrm{w} / \mathrm{v})$ agarose gel (BioWest Regular Agaros G-10, catalogue no. 111860; Gene Co. Ltd, Hong Kong, China) for electrophoresis and determination of genotypes.

\section{Statistical analysis}

To compare the normal-weight and obese groups in the cross-sectional survey or the intervention trial, parametric variables were analysed with a univariate general linear model using age as a covariate. Based on the obesity prevalence in adult Shenzhen males at different ages ${ }^{(41)}$ and the age composition in the present study, age was divided into three periods: $<35$ years, $35-<50$ years and $\geq 50$ years. To examine the vitamin D status and SNP genotypes in the cross-sectional survey, the $\chi^{2}$ method was applied to test the differences within each age period followed by Cochran's and Mantel-Haenszel statistics controlling any effects of age. The SNP were analysed with various genetic models ${ }^{(51)}$ including genotypic frequency, allelic frequency (multiplicative model), dominant model and recessive model. Partial correlation analysis was conducted between the plasma 25(OH)D concentrations and each of the SNP genotypes adjusting for group, age and BMI. The frequencies of each SNP in both groups were tested for Hardy-Weinberg equilibrium. Within the same group in the intervention trial, data were analysed with the paired-samples $t$ test. The Mann-Whitney $U$ test was used to analyse the data with non-normal or unknown distribution. Comparisons were considered statistically significant if $P<0 \cdot 05$.

\section{Results}

\section{Vitamin D status and SNP of VDR gene}

The biometric and biochemical characteristics of the participants (eighty-two normal-weight and ninety-nine obese men) are summarized in Table 1 . The majority of the indices examined were significantly worse for the obese group compared with the normal-weight group $(P<0 \cdot 01)$. Only the mean concentrations of plasma $25(\mathrm{OH}) \mathrm{D}(55.3$ (SD 12.2) $\mathrm{nmol} / \mathrm{l}$ in the normal-weight group and 54.8 (sD 13.4) $\mathrm{nmol} / \mathrm{l}$ in the obese group, $P=0.877$ ) and creatinine $(P=0.301)$ were not significantly different. 
Table 1 Biometric and biochemical data of the adult males for the case-control study, Shenzhen City, Guangdong Province, China

\begin{tabular}{|c|c|c|c|c|c|}
\hline \multirow[b]{2}{*}{ Index } & \multicolumn{2}{|c|}{ Normal weight ( $n$ 82) } & \multicolumn{2}{|c|}{ Obese ( $n$ 99) } & \multirow[b]{2}{*}{$P$ value* } \\
\hline & Mean & SD & Mean & SD & \\
\hline Age (years) & 33.4 & $9 \cdot 3$ & 43.4 & $10 \cdot 1$ & $<0.001$ \\
\hline BMI $\left(\mathrm{kg} / \mathrm{m}^{2}\right)$ & $21 \cdot 0$ & 1.5 & 29.9 & $2 \cdot 3$ & $<0.001$ \\
\hline Waist:hip ratio & 0.83 & 0.06 & 0.94 & 0.06 & $<0.001$ \\
\hline Systolic blood pressure $(\mathrm{mmHg})$ & $105 \cdot 6$ & 8.2 & 128.9 & $16 \cdot 2$ & $<0.001$ \\
\hline Diastolic blood pressure $(\mathrm{mmHg})$ & $69 \cdot 3$ & $5 \cdot 3$ & $86 \cdot 7$ & $10 \cdot 7$ & $<0.001$ \\
\hline Fasting plasma glucose (mmol/l) & 4.84 & 0.35 & 5.52 & 1.38 & 0.007 \\
\hline TAG $(\mathrm{mmol} / \mathrm{l})$ & 0.87 & 0.33 & $2 \cdot 37$ & 1.73 & $<0.001$ \\
\hline Total cholesterol (mmol/l) & 4.28 & 0.54 & $5 \cdot 21$ & 0.96 & $<0.001$ \\
\hline HDL cholesterol (mmol/l) & 1.32 & 0.19 & $1 \cdot 10$ & 0.23 & $<0.001$ \\
\hline LDL cholesterol (mmol/l') & 2.55 & 0.42 & 3.37 & 0.72 & $<0.001$ \\
\hline Uric acid $(\mu \mathrm{mol} / \mathrm{l})$ & $307 \cdot 6$ & $49 \cdot 3$ & $384 \cdot 2$ & $75 \cdot 0$ & $<0.001$ \\
\hline Creatinine $(\mu \mathrm{mol} / \mathrm{l})$ & 89.6 & 9.6 & 91.4 & 12.5 & 0.301 \\
\hline Plasma 25(OH)D (nmol/l) & $55 \cdot 3$ & $12 \cdot 2$ & $54 \cdot 8$ & 13.4 & 0.877 \\
\hline
\end{tabular}

25(OH)D, 25-hydroxyvitamin D.

${ }^{\star}$ The $P$ value for age was obtained using the independent-samples $t$ test; the $P$ values of all other parameters were obtained by a univariate general linear model with age as a covariate.

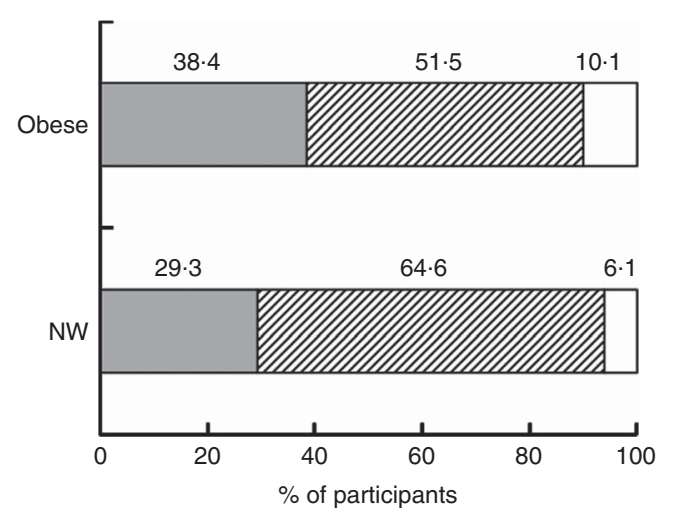

Fig. 1 Percentage distribution of circulating serum 25-hydroxyvitamin $\mathrm{D}$ concentrations in normal-weight (NW) and obese males $(\square,<50 \mathrm{nmol} / \mathrm{l} ; \square, \quad 50-<75 \mathrm{nmol} / / ; \square, 75-250 \mathrm{nmol} / \mathrm{l})$, Shenzhen City, Guangdong Province, China. The percentages of participants in the different categories of vitamin D status did not differ between the NW ( $n$ 82) and obese ( $n$ 99) groups, with or without adjustment for age $(P>0.05)$

None of the indicators were correlated with BMI, waist:hip ratio, blood pressure, plasma lipid, uric acid or creatinine $(P>0 \cdot 10)$. The calculated Ca intakes based on the FFQ in normal-weight and obese groups were 650.6 (SD 282.7) $\mathrm{mg} / \mathrm{d}$ and 639.1 (sD 266.2) $\mathrm{mg} / \mathrm{d}$, respectively (MannWhitney $U$ test, $P=0.947)$. Also, the percentage of participants with plasma $25(\mathrm{OH}) \mathrm{D}$ concentration $<50 \mathrm{nmol} / \mathrm{l}$, $50-<75 \mathrm{nmol} / 1$ and $75-250 \mathrm{nmol} / 1$ in both groups $(38.4 \%$, $51.5 \%, 10 \cdot 1 \%$ for obese $v .29 \cdot 3 \%, 64.6 \%, 6 \cdot 1 \%$ for normal weight) were not significantly different without $(P=0 \cdot 192)$ or with $(P=0.749)$ adjustment for age (Fig. 1$)$. Thirty to forty per cent of participants in both groups had a plasma $25(\mathrm{OH}) \mathrm{D}$ concentration $<50 \mathrm{nmol} / \mathrm{l}$, and none had a concentration $<25 \mathrm{nmol} / 1$ or $>250 \mathrm{nmol} / \mathrm{l}$.

The genotypic and allelic frequencies of the five $V D R$ SNP are summarized in the online supplementary material, Supplemental Table 2 . The $P$ values of statistical analyses are listed in Table 2. Only the genotypic frequency of rs3782905 differed significantly between the two groups when age was considered as a covariate in the Cochran's and Mantel-Haenszel statistics $(P=0 \cdot 043)$. Tendency to be different between the obese and the normal-weight groups $(0.05<P<0 \cdot 10)$ was found in the genotypic frequency and dominant model of $A p a \mathrm{I}$ in the age period of $35-<50$ years, and in the allelic frequency and recessive model of $C d x-2$ with age as a covariate in the Cochran's and Mantel-Haenszel statistics. The remaining $P$ values for comparisons of the five SNP in various genetic models were not significantly different between the two groups $(P>0 \cdot 10)$. No $V D R$ genotypes based on the SNP had a correlation with plasma $25(\mathrm{OH}) \mathrm{D}$ when adjusted for age, BMI and experimental group $(P>0.05$, see online supplementary material, Supplemental Table 3).

\section{Biometric profile and lifestyle factors in the intervention trial}

Excluding those with significant changes of lifestyle and final BMI (>3\%), twenty-one participants of each group were accepted for data analyses. The biometric characteristics of the two groups were similar to those in the cross-sectional survey (see online supplementary material, Supplemental Table 4). The final BMI levels were $21.8(\mathrm{sD} 1.2) \mathrm{kg} / \mathrm{m}^{2}$ for the normal-weight group and $30 \cdot 2$ (SD 1.7$) \mathrm{kg} / \mathrm{m}^{2}$ for the obese group, without significant differences compared with the respective values before vitamin D supplementation.

The dietary vitamin D intakes of the two groups in the past 1 year were not significantly different (Mann-Whitney $U$ test, $P=0.910$; median $67 \cdot 1 \mathrm{IU} / \mathrm{d}$ or $1.68 \mu \mathrm{g} / \mathrm{d}$ ). During the intervention trial, all participants maintained their normal dietary habits and data collected by the FFQ showed they did not increase their intake of vitamin D-rich foods. The duration of sun exposure with summer clothing (usually T-shirt and trousers) from 10.00 to 15.00 hours 
Table 2 Statistical comparisons ( $P$ values) of five VDR SNP between the obese $(n 99)$ and normal-weight $(n 82)$ adult males, Shenzhen City, Guangdong Province, China, analysed with different genetic models

\begin{tabular}{|c|c|c|c|c|c|}
\hline Genetic model $^{\star}$ & SNP† & $<35$ years & $35-<50$ years & $\geq 50$ years & Cochran's and Mantel-Haenszel \\
\hline \multirow[t]{5}{*}{ Genotypic frequency } & Taql & 0.788 & 0.562 & 0.360 & 0.366 \\
\hline & Apal & 0.330 & 0.090 & 0.786 & 0.123 \\
\hline & rs3782905 & 0.326 & $0 \cdot 101$ & 0.492 & 0.043 \\
\hline & Fokl & 0.574 & 0.592 & 0.299 & 0.596 \\
\hline & $C d x-2$ & 0.400 & 0.353 & 0.758 & 0.408 \\
\hline \multirow[t]{5}{*}{ Allelic frequency } & Taql & 0.792 & 0.570 & 0.375 & 0.374 \\
\hline & Apal & 0.303 & 0.343 & 0.852 & 0.215 \\
\hline & rs3782905 & 0.142 & 0.744 & 0.225 & 0.473 \\
\hline & Fokl & 0.399 & 0.750 & 0.677 & 0.914 \\
\hline & $C d x-2$ & 0.175 & $0 \cdot 127$ & 0.952 & 0.051 \\
\hline \multirow[t]{5}{*}{ Dominant model } & Taql & 0.788 & 0.562 & 0.360 & 0.366 \\
\hline & Apal & 0.664 & 0.088 & 0.786 & 0.144 \\
\hline & rs3782905 & 0.141 & 0.306 & 0.234 & 0.203 \\
\hline & Fokl & 0.292 & 0.417 & 0.234 & 0.780 \\
\hline & $C d x-2$ & 0.183 & 0.334 & 0.786 & 0.157 \\
\hline \multirow[t]{5}{*}{ Recessive model } & Taql & $-\ddagger$ & $-\ddagger$ & $-\ddagger$ & $-\ddagger$ \\
\hline & Apal & 0.137 & 0.440 & $-\ddagger$ & 0.782 \\
\hline & rs3782905 & 0.561 & $0 \cdot 151$ & 0.664 & 0.259 \\
\hline & Fokl & 0.817 & 0.778 & 0.660 & 0.626 \\
\hline & $C d x-2$ & 0.460 & 0.163 & 0.530 & 0.099 \\
\hline
\end{tabular}

VDR, vitamin $\mathrm{D}$ receptor gene.

${ }^{*}$ The dominant model is used for major homozygotes $v$. combination of minor homo- and heterozygotes. The recessive model is used for combination of major homo- and heterozygotes $v$. minor homozygotes.

†RefSNP ID numbers are: rs731236 for Taql, rs7975232 for Apal, rs2228570 for Fokl and rs11568820 for Cdx-2.

$\ddagger$ The $P$ value was not available due to at least one sum of rows or columns being zero.

was not significantly different (Mann-Whitney $U$ test, $P=0.339$; median sun exposure $19.8 \mathrm{~min} / \mathrm{d}$ ). In addition, there were no complaints of feeling uncomfortable or of symptoms potentially caused by vitamin D toxicity ${ }^{(49)}$.

\section{Changes in biochemical indices by vitamin $D$ supplementation}

The changes of IR and serum concentrations of $25(\mathrm{OH}) \mathrm{D}$, iPTH and insulin of both normal-weight and obese groups, before and after the intervention trial, are summarized in Fig. 2. The average baseline serum $25(\mathrm{OH}) \mathrm{D}$ concentrations were $52.8(\mathrm{sD} 17 \cdot 8) \mathrm{nmol} / \mathrm{l}$ for the normal-weight group and $46 \cdot 1$ (SD 9.1) nmol/1 for the obese group, and this difference was not significant $(P=0 \cdot 071)$. Findings were similar to the cross-sectional survey. After vitamin D supplementation, the serum $25(\mathrm{OH}) \mathrm{D}$ concentration of both groups was enhanced significantly $(P<0.001)$, with a $2 \cdot 8$-fold increase for the normal-weight group and a 1.6fold increase for the obese group. Thus the normal-weight group had a significantly higher concentration $(P<0 \cdot 001)$ of serum $25(\mathrm{OH}) \mathrm{D}(181 \cdot 3(\mathrm{sD} 30 \cdot 2) \mathrm{nmol} / \mathrm{l})$ than the obese group (116.7 (sD 20.3) nmol/l) after the intervention trial. All participants in the normal-weight group had serum $25(\mathrm{OH}) \mathrm{D}$ concentration $\geq 75 \mathrm{nmol} / \mathrm{l}$, while $9.5 \%$ of the obese participants still had this index between 50 and $<75 \mathrm{nmol} / \mathrm{l}$.

Either before or after vitamin D supplementation, with age adjusted, iPTH $(P=0.023$ and 0.034 , respectively), fasting serum insulin ( $P=<0.001$ and $0 \cdot 010$, respectively) and HOMA-IR $(P=<0.001$ and 0.023 , respectively) in the obese group were higher $(P<0.05)$ than those in the normal-weight group. However, the fasting serum glucose values did not differ significantly between them $(P=0.465$ and 0.643 , respectively). Before the trial, the normalweight group had a lower glucose concentration $2 \mathrm{~h}$ after the oral glucose challenge test compared with the obese group (data not shown). After vitamin D supplementation, iPTH, fasting serum insulin and HOMA-IR did not change significantly $(P>0.05)$ in the normal-weight group, but decreased significantly in the obese group $(P<0.05)$.

Within each group, lipid profile, uric acid, blood $\mathrm{Ca}$, creatinine, alkaline phosphatase and aspartate aminotransferase did not significantly change $(P>0.05)$ after vitamin D supplementation (see online supplementary material, Supplemental Table 5). However, in the respective normal reference ranges, HDL cholesterol decreased $(P=0.036)$ and aspartate aminotransferase increased $(P=0.032)$ in the obese group, and uric acid increased $(P=0.014)$ in the normal-weight group.

\section{Discussion}

Among the risk factors associated with the growing incidence of various chronic diseases in the Chinese population, including obesity, vitamin D nutritional status has been gaining attention. Only a small number of studies have reported the high prevalence of hypovitaminosis D among the Chinese population. A dual-centre study demonstrated that more than $90 \%$ of young women in both Hong Kong and Beijing had 25(OH)D concentrations 
(a)

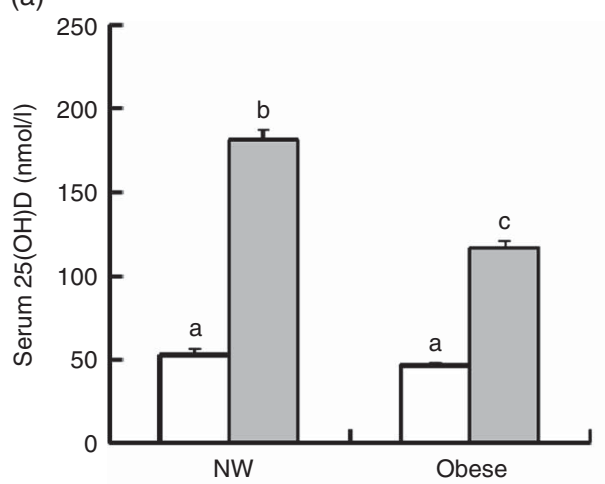

(c)

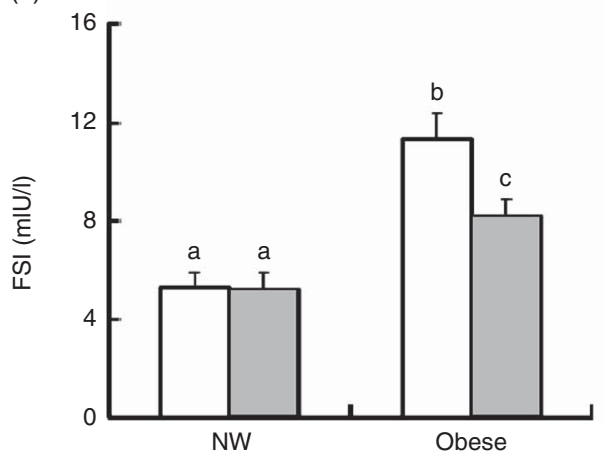

(b)

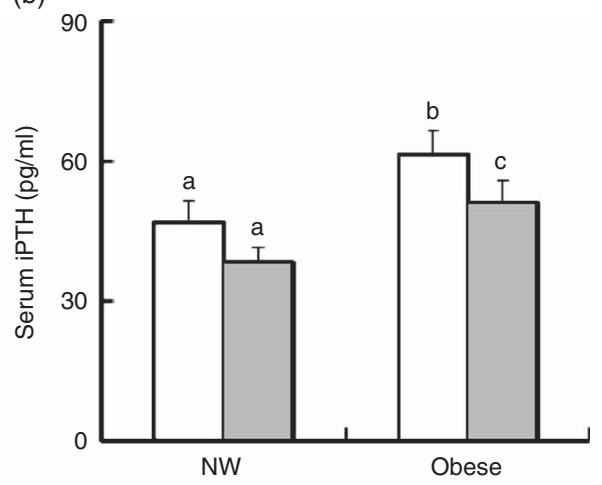

(d)

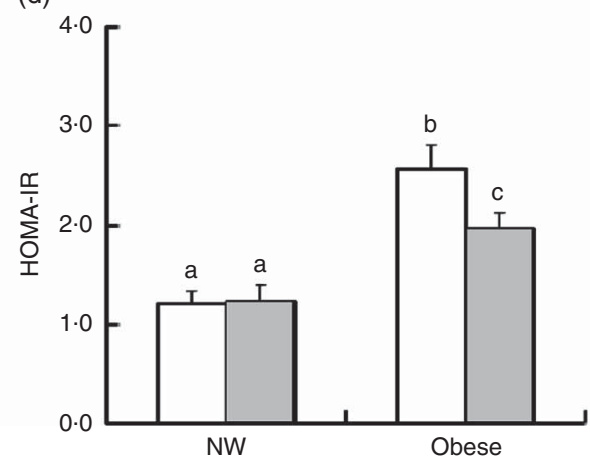

Fig. 2 Changes in fasting serum concentrations of (a) 25-hydroxyvitamin $\mathrm{D}(25(\mathrm{OH}) \mathrm{D})$, (b) intact parathyroid hormone (iPTH), (c) insulin (FSI) and (d) homeostasis model assessment of insulin resistance index (HOMA-IR), before ( $\square$ ) and after ( $\square$ ) the vitamin D supplementation trial in normal-weight (NW) and obese males, Shenzhen City, Guangdong Province, China. Data are means with their standard errors represented by vertical bars (twenty-one participants per group). ${ }^{\mathrm{a}, \mathrm{b}, \mathrm{c}}$ Within the same group, or within the same stage between groups using age as a covariate, data with unlike superscript letters were significantly different $(P<0.05)$. With age adjusted, before and after the trial, $P$ values for $25(\mathrm{OH}) \mathrm{D}$ were 0.071 and $<0.001$, for iPTH were 0.023 and 0.034 , for FSI were $<0.001$ and 0.010 , and for HOMA-IR were $<0.001$ and 0.023 , respectively. Without adjustment, before and after the trial, $P$ values for 25(OH)D were 0.134 and $<0.001$, for iPTH were 0.038 and 0.030 , for FSI were $<0.001$ and 0.003 , and for HOMA-IR were $<0.001$ and 0.003 , respectively

$\leq 50 \mathrm{nmol} / \mathrm{l}$ in spring, and $18 \%$ of young women in Hong Kong had 25(OH)D concentrations $\leq 25 \mathrm{nmol} / \mathrm{l}^{(52)}$. A survey, conducted in Beijing $\left(\sim 40^{\circ} \mathrm{N}\right)$ and Shanghai $\left(\sim 31^{\circ} \mathrm{N}\right)$ from April to June in 2005 , revealed that $69 \%$ of the middle-aged and elderly people were vitamin D 'deficient' $(25(\mathrm{OH}) \mathrm{D}<50 \mathrm{nmol} / \mathrm{l})$ and $24 \%$ were vitamin D 'insufficient' $(50 \mathrm{nmol} / 1 \leq 25(\mathrm{OH}) \mathrm{D}<75 \mathrm{nmol} / \mathrm{l})^{(53)}$. Furthermore, blood samples collected during April and May from healthy pregnant women and their newborn infants in a Beijing hospital indicated that none of the subjects had serum 25(OH)D concentration $>75 \mathrm{nmol} / 1$ and half of them were in 'severe vitamin D deficiency' $(25(\mathrm{OH}) \mathrm{D}$ $<25 \mathrm{nmol} / \mathrm{l})^{(54)}$.

In the present study, approximately a third of adult males in Shenzhen, a southern Chinese city located at $22 \cdot 5^{\circ} \mathrm{N}$, had circulating $25(\mathrm{OH}) \mathrm{D}$ concentration $<50 \mathrm{nmol} / \mathrm{l}$, and approximately $90 \%$ had a concentration $<75 \mathrm{nmol} / 1$ (even during summer). Although the study size was relatively small, participant selection adhered to strict inclusion criteria to limit potential confounders and generate reliable data. These low vitamin D statuses may arise from people limiting their sun exposure to avoid hot weather and sunburn despite sunny conditions in the low-altitude regions. Besides, variable responsiveness to sun exposure is another newly assumed mechanism underlying the low vitamin D status ${ }^{(55)}$, which needs further investigation in this Chinese population.

Obese individuals have a lower circulating $25(\mathrm{OH}) \mathrm{D}$ concentration than those of normal weight ${ }^{(19-23)}$. However, in adult males living in subtropical China, we did not find a significantly lower vitamin D status in the obese group. The following factors should be considered when interpreting this apparent inconsistency. First, the 25-hydroxylase enzyme that catalyses hydroxylation of vitamin $\mathrm{D}$ into $25(\mathrm{OH}) \mathrm{D}$ may not have been saturated or the fat storage effect was weak at the present baseline vitamin D intake of $<50 \mu \mathrm{g} / \mathrm{d}(2000 \mathrm{IU} / \mathrm{d})$ and serum $25(\mathrm{OH}) \mathrm{D}$ concentration of $<100 \mathrm{nmol} / \mathrm{l}$, as previously reported $^{(56)}$. However, with increasing intake or supplementation of vitamin $\mathrm{D}$, the fat storage effect and the decreased bioavailability of vitamin D in the obese participants ${ }^{(20)}$ were revealed. Second, the mean BMI of our obese participants was lower than those in Western population studies; the BMI range for obesity is $\geq 28 \cdot 0 \mathrm{~kg} / \mathrm{m}^{2}$ 
in China but $\geq 30 \cdot 0 \mathrm{~kg} / \mathrm{m}^{2}$ in Western countries ${ }^{(57)}$. This is because Chinese populations are more likely to develop negative health consequences at a lower BMI than Caucasians. Third, other reasons associated with genetic makeup, lifestyle and environmental differences among various populations may contribute to the differences observed.

The bioactive form of vitamin $\mathrm{D}, 1,25(\mathrm{OH})_{2} \mathrm{D}$, is actually a hormone with its serum concentration strictly controlled by sophisticated mechanisms. Serum $1,25(\mathrm{OH})_{2} \mathrm{D}$ is resistant to a broad range of vitamin D $(25,250$ or $1250 \mu \mathrm{g} / \mathrm{d}$ for 8 weeks) or $25(\mathrm{OH}) \mathrm{D}$ (10, 20 or $50 \mu \mathrm{g} / \mathrm{d}$ for 4 weeks) intakes $^{(45)}$. It can enter many types of cell to form a complex with the VDR, modulates the expressions of more than 200 genes via vitamin D response elements (VDRE) and performs various biological functions ${ }^{(58)}$. VDR is important in the function of $1,25(\mathrm{OH})_{2} \mathrm{D}$, and itself is a $1,25(\mathrm{OH})_{2} \mathrm{D}$-targeted gene with $\mathrm{VDRE}^{(59)}$. Multiple studies have been performed to explore the relationship between $V D R$ gene SNP and VDR-mediated biological activities or diseases, and to understand the mechanisms ${ }^{(37,38)}$. $C d x-2$ polymorphism is located in the promoter region and thus its variant has the possibility to impact on VDR transcription $^{(35)}$. FokI variation occurs in the second exon of $V D R$ and its polymorphism results in two different lengths and activities of VDR peptides ${ }^{(36,37)}$. Near the $3^{\prime}$-end of $V D R$, $B s m \mathrm{I}$ and $A p a \mathrm{I}$ are located in the intron, between exons 8 and 9, and TaqI is in exon $9^{(37)}$. These three polymorphisms have a strong linkage disequilibrium extending into the 3 '-regulatory region containing the untranslated region. The $3^{\prime}$-untranslated region of a gene is usually involved in its own expression regulation and, therefore, $B s m \mathrm{I}, A p a \mathrm{I}$ and TaqI were reported to have associations with a variety of diseases ${ }^{(38)}$. However, there are many $\mathrm{SNP}$ in the intron region of $V D R$ with unknown biological functions. The rs3782905 SNP (between exons 2 and 3 with unknown function) in females aged 35-80 years $\left(n\right.$ 1773) ${ }^{(39)}$ and ApaI SNP in postmenopausal women $(n 140)^{(40)}$ are associated with obesity, whereby BMI was not defined as clearly as the two groups in our study. In our cross-sectional survey involving 181 adult males, the significance $(P=0.043)$ of $\mathrm{rs} 3782905$ was demonstrated, while ApaI had only difference tendency $(P=0.090)$ in those aged $35-<50$ years. Also, $C d x-2$ tended to be different in our findings based on allelic frequency $(P=0.051)$ and the recessive model $(P=0.099)$. The consistency and inconsistency of our findings compared with previous studies ${ }^{(39,40)}$ might be partly explained by our BMI grouping methods as well as the genetic variation of VDR SNP in different populations ${ }^{(60)}$.

$P T H$ is another target gene of $1,25(\mathrm{OH})_{2} \mathrm{D}$ with a negative VDRE on its promoter ${ }^{(61)}$. Transactivation of $P T H$ is sensitive to decreases in $1,25(\mathrm{OH})_{2} \mathrm{D}$ in order to tightly maintain its constant level. However, prolonged high levels of PTH can impair intestinal $\mathrm{Ca}$ absorption and stimulates osteoclasts to dissolve the mineralized collagen matrix in bone, causing many bone diseases ${ }^{(15)}$. Holick and co-workers ${ }^{(12)}$ demonstrated the significant reduction of PTH and its inverse association with serum 25(OH)D when adults with an initial $25(\mathrm{OH}) \mathrm{D}$ concentration below $50 \mathrm{nmol} / 1$ received vitamin D supplementation. Recently, the circulating PTH level was reported to become stable at serum 25(OH)D level of $46 \cdot 2 \mathrm{nmol} / \mathrm{l}$, as estimated by the segmented model ${ }^{(62)}$. In obese individuals with low vitamin D status, secondary hyperparathyroidism and elevated serum PTH levels are also evident ${ }^{(63-65)}$. Steingrimsdottir et al. ${ }^{(66)}$ found that at a low serum $25(\mathrm{OH}) \mathrm{D}$ concentration of $<18 \mathrm{ng} / \mathrm{ml}(45 \mathrm{nmol} / \mathrm{l})$, Ca intake of $<800 \mathrm{mg} / \mathrm{d}$ (compared with $>1200 \mathrm{mg} / \mathrm{d}$ ) was significantly associated with a high serum PTH. The Ca intakes of the two groups in our intervention trial were likely to be $<800 \mathrm{mg} / \mathrm{d}$, like those of the groups in the cross-sectional survey, and based on their recorded dietary patterns $\mathrm{Ca}$ intake probably did not change throughout the trial. More importantly, their baseline circulating 25(OH)D concentration was $>18 \mathrm{ng} / \mathrm{ml}$ and there was no difference between groups. Thus the $\mathrm{Ca}$ intakes probably had little or no contribution to the changes of serum iPTH concentrations after the vitamin D supplementation trial. Therefore, the significant reduction in serum PTH concentration in the obese group (from 61.5 to $51.1 \mathrm{pg} / \mathrm{ml}$, $P=0.037)$ and the decline in the normal-weight group (from 47.1 to $38.3 \mathrm{pg} / \mathrm{ml}, P=0.058$ ) were likely to be attributed to the significantly improved serum $25(\mathrm{OH}) \mathrm{D}$ concentrations.

Although cross-sectional analyses and laboratory experiments suggest that vitamin D deficiency and obesity are associated with the weakened response of cells to insulin, predisposed IR and pancreatic $\beta$-cell dysfunction ${ }^{(26,27,67-69)}$, intervention outcomes were not always consistent. Variations may be due to differences in study populations and intervention protocols. Using obese Chinese males as subjects, we tested the benefit of largedose vitamin D supplementation at $50000 \mathrm{IU}(1250 \mu \mathrm{g})$ once weekly for 8 weeks, similar to the protocol applied previously $^{(12,45,47)}$; this is a recommended strategy to treat adults who are vitamin D 'deficient' ${ }^{(10)}$. As a result, the IR status and insulin sensitivity in this population were significantly improved, consistent with the recent findings from India and New Zealand ${ }^{(70,71)}$.

\section{Conclusions}

In summary, baseline vitamin D nutritional status did not differ between obese and normal-weight men living in subtropical China in summer. However, oral high-dose vitamin D supplementation revealed decreased vitamin D bioavailability in obese men and reduced their hypersecretion of PTH and insulin resistance. In addition, the rs3782905 SNP of the $V D R$ gene was associated with obesity. The SNP of $C d x-2$ and $A p a \mathrm{I}$ are candidates for future study in the relationship between $V D R \mathrm{SNP}$ and 
obesity, especially in a Chinese population. Finally, the generally held viewpoint in Chinese populations that highdose administration of fat-soluble vitamin $\mathrm{D}$ has negative side-effects was a significant obstacle to recruiting a larger number of volunteers and implementing a longer trial period. Consequently a placebo control group or a placebo experimental stage was not established in the present study. Large-scale human trials avoiding these limitations are required to corroborate the conclusions and implications of our study.

\section{Acknowledgements}

Acknowledgements: The authors thank Ms Ya-Juan Song, Ms Willa Dong and Mr Shi-Jie Zheng for their help in the intervention trial, manuscript preparation and data analysis, respectively. Financial support: This project was funded by grants from the Danone Institute; China Diet Nutrition Research \& Communication (grant number DIC2010-03); Science \& Technology Innovation Commission of Shenzhen Municipality (grant number JCYJ20130402154801097); and the National Key Technology Research and Development Program of China (grant number 2012BAI02B02). None of these agencies had any role in the design, analysis or writing of this article. Conflict of interest: None. Authorship: J.-C.Z. was responsible for the study design, data analysis and manuscript preparation. Y.-M.Z., Z.C., J.-L.M. and J.W. contributed to sample preparation and management and biomarker assays. F.-Z.X. and Y.-H.W. conducted blood sampling. P.G., J.P., J.X. and X.-L.L. coordinated the departments involved in the study and provided general assistance with the study. All authors have read and approved the final manuscript. Ethics of human subject participation: The trial was approved by the Ethics Committee of the Shenzhen Center for Chronic Disease Control (trial registration number on ClinicalTrials.gov site: NCT01781169).

\section{Supplementary material}

To view supplementary material for this article, please visit http://dx.doi.org/10.1017/S1368980014002845

\section{References}

1. Xi B, Liang Y, He T et al. (2012) Secular trends in the prevalence of general and abdominal obesity among Chinese adults, 1993-2009. Obes Rev 13, 287-296.

2. Li XY, Jiang Y, Hu N et al. (2012) Prevalence and characteristic of overweight and obesity among adults in China, 2010. Zhonghua Yu Fang Yi Xue Za Zhi 46, 683-686.

3. Wood RJ (2008) Vitamin D and adipogenesis: new molecular insights. Nutr Rev 66, 40-46.

4. Foss YJ (2009) Vitamin D deficiency is the cause of common obesity. Med Hypotheses 72, 314-321.

5. Vanlint S (2013) Vitamin D and obesity. Nutrients 5, 949-956.
6. Vinh Quoc Lu'o'ng K \& Nguyen LT (2013) The beneficial role of vitamin $\mathrm{D}$ in obesity: possible genetic and cell signaling mechanisms. Nutr J 12, 89.

7. Jones G (2008) Pharmacokinetics of vitamin D toxicity. Am J Clin Nutr 88, issue 2, 582S-586S.

8. Pearce SH \& Cheetham TD (2010) Diagnosis and management of vitamin D deficiency. BMJ 340, b5664.

9. Martini LA \& Wood RJ (2006) Vitamin D status and the metabolic syndrome. Nutr Rev 64, 479-486.

10. Holick MF, Binkley NC, Bischoff-Ferrari HA et al. (2011) Evaluation, treatment, and prevention of vitamin D deficiency: an Endocrine Society clinical practice guideline. J Clin Endocrinol Metab 96, 1911-1930.

11. Institute of Medicine (2011) Dietary Reference Intakes for Calcium and Vitamin D. Washington, DC: The National Academies Press.

12. Malabanan A, Veronikis IE \& Holick MF (1998) Redefining vitamin D insufficiency. Lancet 351, 805-806.

13. Kendrick J, Targher G, Smits G et al. (2009) 25Hydroxyvitamin D deficiency is independently associated with cardiovascular disease in the Third National Health and Nutrition Examination Survey. Atherosclerosis 205, $255-260$.

14. Forrest KY \& Stuhldreher WL (2011) Prevalence and correlates of vitamin D deficiency in US adults. Nutr Res 31, 48-54.

15. Holick MF (2007) Vitamin D deficiency. $N$ Engl J Med 357, 266-281.

16. Holick MF \& Chen TC (2008) Vitamin D deficiency: a worldwide problem with health consequences. Am J Clin Nutr 87, issue 4, 1080S-1086S.

17. Mithal A, Wahl DA, Bonjour JP et al. (2009) Global vitamin D status and determinants of hypovitaminosis D. Osteoporos Int 20, $1807-1820$.

18. Holick MF (2009) Vitamin D status: measurement, interpretation, and clinical application. Ann Epidemiol 19, 73-78.

19. Liel Y, Ulmer E, Shary J et al. (1988) Low circulating vitamin D in obesity. Calcif Tissue Int 43, 199-201.

20. Wortsman J, Matsuoka LY, Chen TC et al. (2000) Decreased bioavailability of vitamin D in obesity. Am J Clin Nutr 72, 690-693.

21. Rosenstreich SJ, Rich C \& Volwiler W (1971) Deposition in and release of vitamin $D_{3}$ from body fat: evidence for a storage site in the rat. J Clin Invest 50, 679-687.

22. Ashraf A, Alvarez J, Saenz K et al. (2009) Threshold for effects of vitamin D deficiency on glucose metabolism in obese female African-American adolescents. J Clin Endocrinol Metab 94, 3200-3206.

23. Blum M, Dolnikowski G, Seyoum E et al. (2008) Vitamin D(3) in fat tissue. Endocrine 33, 90-94.

24. Zeyda M \& Stulnig TM (2009) Obesity, inflammation, and insulin resistance - a mini-review. Gerontology 55, 379-386.

25. Codogno P \& Meijer AJ (2010) Autophagy: a potential link between obesity and insulin resistance. Cell Metab 11, 449-451.

26. Alvarez JA \& Ashraf A (2010) Role of vitamin D in insulin secretion and insulin sensitivity for glucose homeostasis. Int J Endocrinol 2010, 351385.

27. Chiu KC, Chu A, Go VL et al. (2004) Hypovitaminosis D is associated with insulin resistance and $\beta$ cell dysfunction. $A m$ J Clin Nutr 79, 820-825.

28. Muscogiuri G, Sorice GP, Prioletta A et al. (2010) 25Hydroxyvitamin D concentration correlates with insulinsensitivity and BMI in obesity. Obesity (Silver Spring) 18, 1906-1910.

29. Manco M, Calvani M, Nanni G et al. (2005) Low 25hydroxyvitamin D does not affect insulin sensitivity in obesity after bariatric surgery. Obes Res 13, 1692-1700.

30. Kumar R \& Thompson JR (2011) The regulation of parathyroid hormone secretion and synthesis. J Am Soc Nephrol 22, 216-224. 
31. Lips P (2006) Vitamin D physiology. Prog Biophys Mol Biol 92, 4-8.

32. Burton GR, Guan Y, Nagarajan R et al. (2002) Microarray analysis of gene expression during early adipocyte differentiation. Gene 293, 21-31.

33. Gerhold DL, Liu F, Jiang G et al. (2002) Gene expression profile of adipocyte differentiation and its regulation by peroxisome proliferator-activated receptor- $\gamma$ agonists. Endocrinology 143, 2106-2118.

34. Kong J \& Li YC (2006) Molecular mechanism of 1,25-dihydroxyvitamin $\mathrm{D}_{3}$ inhibition of adipogenesis in 3T3-L1 cells. Am J Physiol Endocrinol Metab 290, E916-E924.

35. Arai H, Miyamoto KI, Yoshida M et al. (2001) The polymorphism in the caudal-related homeodomain protein $\mathrm{Cdx}$ 2 binding element in the human vitamin $\mathrm{D}$ receptor gene. J Bone Miner Res 16, 1256-1264.

36. Arai H, Miyamoto K, Taketani Y et al. (1997) A vitamin D receptor gene polymorphism in the translation initiation codon: effect on protein activity and relation to bone mineral density in Japanese women. J Bone Miner Res $\mathbf{1 2}$ 915-921.

37. Uitterlinden AG, Fang Y, Van Meurs JB et al. (2004) Genetics and biology of vitamin D receptor polymorphisms. Gene 338, 143-156.

38. Valdivielso JM \& Fernandez E (2006) Vitamin D receptor polymorphisms and diseases. Clin Chim Acta 371, 1-12.

39. Ochs-Balcom HM, Chennamaneni R, Millen AE et al. (2011) Vitamin D receptor gene polymorphisms are associated with adiposity phenotypes. Am J Clin Nutr 93, 5-10.

40. Binh TQ, Nakahori Y, Hien VT et al. (2011) Correlations between genetic variance and adiposity measures, and gene $\times$ gene interactions for obesity in postmenopausal Vietnamese women. J Genet $\mathbf{9 0}, 1-9$.

41. Lei L, Zhou H, Xiong J et al. (2011) Analysis of the current status on overweight and obesity in Shenzhen. J Public Health Prev Med 22, 36-37.

42. Chen C \& Lu FC (2004) The guidelines for prevention and control of overweight and obesity in Chinese adults. Biomed Environ Sci 17, Suppl., 1-36.

43. US Department of Agriculture, Agricultural Research Service (2011) USDA national nutrient database for standard reference, release 24. Nutrient Data Laboratory Home Page. http:// www.ars.usda.gov/ba/bhnrc/ndl (accessed February 2012).

44. Lohman TG, Roche AF \& Martorell R (1988) Anthropometric Standardization Reference Manual. Champaign, IL: Human Kinetics Books.

45. Barger-Lux MJ, Heaney RP, Dowell S et al. (1998) Vitamin D and its major metabolites: serum levels after graded oral dosing in healthy men. Osteoporos Int 8, 222-230.

46. Hathcock JN, Shao A, Vieth R et al. (2007) Risk assessment for vitamin D. Am J Clin Nutr 85, 6-18.

47. Heaney RP, Recker RR, Grote J et al. (2011) Vitamin D(3) is more potent than vitamin D(2) in humans. J Clin Endocrinol Metab 96, E447-E452.

48. Holick MF (2004) Sunlight and vitamin D for bone health and prevention of autoimmune diseases, cancers, and cardiovascular disease. Am J Clin Nutr 80, 6 Suppl., 1678S-1688S.

49. Alshahrani F \& Aljohani N (2013) Vitamin D: deficiency, sufficiency and toxicity. Nutrients 5, 3605-3616.

50. Matthews DR, Hosker JP, Rudenski AS et al. (1985) Homeostasis model assessment: insulin resistance and $\beta$-cell function from fasting plasma glucose and insulin concentrations in man. Diabetologia 28, 412-419.

51. Lewis CM (2002) Genetic association studies: design, analysis and interpretation. Brief Bioinform 3, 146-153.

52. Woo J, Lam CW, Leung J et al. (2008) Very high rates of vitamin $\mathrm{D}$ insufficiency in women of child-bearing age living in Beijing and Hong Kong. Br J Nutr 99, 1330-1334.

53. Lu L, Yu Z, Pan A et al. (2009) Plasma 25-hydroxyvitamin D concentration and metabolic syndrome among middle-aged and elderly Chinese individuals. Diabetes Care 32, $1278-1283$.

54. Song SJ, Si S, Liu J et al. (2013) Vitamin D status in Chinese pregnant women and their newborns in Beijing and their relationships to birth size. Public Health Nutr 16, 687-692.

55. Binkley N, Novotny R, Krueger D et al. (2007) Low vitamin D status despite abundant sun exposure. J Clin Endocrinol Metab 92, 2130-2135.

56. Heaney RP, Armas LA, Shary JR et al. (2008) 25Hydroxylation of vitamin $\mathrm{D}_{3}$ : relation to circulating vitamin $\mathrm{D}_{3}$ under various input conditions. Am J Clin Nutr 87, 1738-1742.

57. Bei-Fan Z (2002) Predictive values of body mass index and waist circumference for risk factors of certain related diseases in Chinese adults: study on optimal cut-off points of body mass index and waist circumference in Chinese adults. Asia Pac J Clin Nutr 11, Suppl. 8, S685-S693.

58. Ramagopalan SV, Heger A, Berlanga AJ et al. (2010) A ChIPseq defined genome-wide map of vitamin D receptor binding: associations with disease and evolution. Genome Res 20, 1352-1360.

59. Maestro B, Davila N, Carranza MC et al. (2003) Identification of a vitamin D response element in the human insulin receptor gene promoter. I Steroid Biochem Mol Biol 84, 223-230.

60. Lins TC, Vieira RG, Grattapaglia D et al. (2011) Population analysis of vitamin D receptor polymorphisms and the role of genetic ancestry in an admixed population. Genet $\mathrm{Mol}$ Biol 34, 377-385.

61. Kim MS, Fujiki R, Murayama A et al. (2007) $1 \alpha, 25(\mathrm{OH})_{2} \mathrm{D}_{3^{-}}$ induced transrepression by vitamin $\mathrm{D}$ receptor through E-box-type elements in the human parathyroid hormone gene promoter. Mol Endocrinol 21, 334-342.

62. Saliba W, Barnett O, Rennert HS et al. (2011) The relationship between serum $25(\mathrm{OH}) \mathrm{D}$ and parathyroid hormone levels. Am J Med 124, 1165-1170.

63. Bell NH, Epstein S, Greene A et al. (1985) Evidence for alteration of the vitamin D-endocrine system in obese subjects. J Clin Invest 76, 370-373.

64. Hamoui N, Anthone G \& Crookes PF (2004) Calcium metabolism in the morbidly obese. Obes Surg 14, 9-12.

65. Snijder MB, van Dam RM, Visser M et al. (2005) Adiposity in relation to vitamin $\mathrm{D}$ status and parathyroid hormone levels: a population-based study in older men and women. J Clin Endocrinol Metab 90, 4119-4123.

66. Steingrimsdottir L, Gunnarsson $\mathrm{O}$, Indridason $\mathrm{OS}$ et al. (2005) Relationship between serum parathyroid hormone levels, vitamin D sufficiency, and calcium intake. JAMA 294, 2336-2341.

67. Riachy R, Vandewalle B, Moerman E et al. (2006) 1,25Dihydroxyvitamin $\mathrm{D}_{3}$ protects human pancreatic islets against cytokine-induced apoptosis via down-regulation of the Fas receptor. Apoptosis 11, 151-159.

68. Norman AW, Frankel JB, Heldt AM et al. (1980) Vitamin D deficiency inhibits pancreatic secretion of insulin. Science 209, 823-825.

69. Kabadi SM, Lee BK \& Liu L (2012) Joint effects of obesity and vitamin D insufficiency on insulin resistance and type 2 diabetes: results from the NHANES 2001-2006. Diabetes Care 35, 2048-2054.

70. Nagpal J, Pande JN \& Bhartia A (2009) A double-blind, randomized, placebo-controlled trial of the short-term effect of vitamin $\mathrm{D}_{3}$ supplementation on insulin sensitivity in apparently healthy, middle-aged, centrally obese men. Diabet Med 26, 19-27.

71. von Hurst PR, Stonehouse W \& Coad J (2010) Vitamin D supplementation reduces insulin resistance in South Asian women living in New Zealand who are insulin resistant and vitamin D deficient - a randomised, placebo-controlled trial. Br J Nutr 103, 549-555. 